研究発表論文

\title{
原風景の生成に関する研究
}

\section{A Study on the Value Production of "the Archetypal Landscapes"}

\author{
吉村 晶子 \\ Akiko YOSHIMURA
}

\begin{abstract}
This paper presents the process and mechanism of the phenomenon in which a person who has moved into a new environment begins to picture the landscape of his or her hometown as "the archetypal landscape". After examining the theoretical framework of this phenomenon, the paper presents a survey of this topic with attention paid to attitude intensity, and considers the processes of formation of and value production of the archetypal landscape. As a result of the work presented here, it was understood that the formation process of the archetypal landscape is one in which "self" and "place" become unified so as to seem to the person as if the landscape is part of his or her being. On the other hand, the production of value of the archetypal landscape was understood as a process through which the totality of the place the person lived in heretofore is viewed as an object; this process typically occurs when the person moves into a new environment. Moreover, it was considered that, in establishing the archetypal landscape, both the processes of formation and value production are necessary. The paper also considers and explains the mechanism behind preservation of self-identity through these processes.
\end{abstract}

Keywords: the archetypal landscape, formation, value production, attitude, memory, identity キーワード：原風景, 形成, 生成, 態度, 記憶, アイデンティティ

\section{1.はじめに}

本研究は, 風景生成研究の立場から, 原風景の成立プロセスと そのメカニズムについて考察することを目的とする。

原風景は，大多数の人が肯定的，積極的意味を与え，また対環 境態度の基礎となるとされていることなどから, 広い研究分野に わたって種々の研究がなされてきた。しかし, これらの既往研究 では, 原風景の記憶の内容, とりわけ, 景観タイプ等の構造を抽 出しょうとするあのは多くみられるむのの, その記憶が活性化さ れるに至るきっかけやしくみについて取り組んだものはほとんど みられず, その生成メカニズムについてはこれまで十分に研究さ れてきたとは言えない。

そこで, 本稿では以下, まず最初に風景生成研究の立場と用語 を確認した上で, 原風景に関する先行研究を概観し, 残されてい る論点を整理し, 次に, その論点に留意して行った原風景調査の 結果を分析し, 原風景の生成プロセスとメカニズムについて考察 を加えることにする。

\section{2. 風景生成研究の立場について}

風景とは, 客観的物理的対象としての環境（存在）のことでは なく, 人間之環境との間に何らかの関係性が生じること（現象） であるとしてとらえるならば，発見的な認識が行われるような風 景体験は, 新たな価值が生成される動態的な変化過程としてとら えることができる。ここで, ある新たな関係性が発生することを 「風景生成」 ${ }^{1)}$ と呼ぶことにすると, 次に述べる点から, 風景の成 立のためには風景生成の現象が必要不可欠であると言える。すな わち, 人間の知覚には通常見慣れたものの知覚を無意識下で自動 的に処理しようとする傾向があり, 環境としてはそこに存在して いてむ，いったんそれに見慣れると，注意を払ったり意識して眺 めたりしなくなる。これは, 認知科学等において「自動化」 ${ }^{2)}$, 現象学において「身体化」3) と呼ばれる現象に相当する。しかし, ある時なんらかのきっかけにより，ある環境の様相に注意が向き，
観照 ${ }^{4)}$ されるようになることがある。これは，自動化に対し「非 自動化 $\rfloor^{5)}$ 之呼ばれる現象であり, 人間之環境之の関係性の变化 がそこにみられる。つまり，風景とは，環境が存在しさえすれば 無条件で成立するあのではなく，人間によって意識され，眺める 対象として「対象化」されてはじめて成立するあのであるという 考え方である。同様の考え方は，これまでにも多くの研究者にみ られ，体験者の立場や態度，また，それまでの生活経験のありよ うが風景の見方を決定づけることが繰り返し言及され，「環境」 と「風景」は区別されるべきものであり ${ }^{6)}$ ，環境が風景として対 象化されるためには没関心的態度が必要である等とされてきた 7 。 ここで, これらの研究において体験者の「立場」「態度」「期待」 「心の構え」等, 様々な用語で呼ばれる, 体験者の環境に対する 構え方のことを，以下，「かまえ」多の用語でとらえることにする 之, 風景之は, 体験者の「かまえ」の变化により見い出され，生 成されるあのであるととらえられる。つまりここで強調したいの は，風景生成研究は，環境之人間の反応の対応関係を固定的・普 遍的なものとして取り出そうとするのではなく，人間と環境の関 係性の变化，すなわち新たな関係性の発生こそが風景現象の本質 であるととらえ，その動態に興味を持つ立場にあることである。

以上, 風景生成研究の立場之用語について確認したが，この立 場に立つ場合, いわゆる「原風景」93 は興味深い研究対象である と言うことができる。すなわち，先行研究では一般に，原風景は 「幼少期に形成されるあの」とされているが (次章参照), ここで, 上記立場に則して考えてみると, 原風景とは「幼少期の体験を素 材に, 後になって生成されたあの」,つまり現場を離れてから風 景生成がなされる例であるという可能性を指摘できる。つまり, 原風景が記憶されている長期の間には, 生活等の变化により環境 に対するかまえが变化することも多々あると考えられるため，原 風景は, 幼少期に確かに見たもの, 直接体験したものであっても, その後の生活経験の蓄積のしかたや体験枠組みの変化に応じ, 後 になって違った形にとらえ直され，新たに生成されたものとして 
とらえられる可能性がある。そしてこのようにとらえて妥当であ れば，現場を離れてあなおなぜ風景が生成されるのかという問題 には研究の余地があり, 原風景が生成されるきっかけやメカニズ ムについて考察することは, これまでノスタルジックに語られが ちだった原風景の現象の意味, ひいては原風景研究の意義の明確 化に寄与できると考えられる。むちろん，この原風景の生成のよ うな現象は，それが現に起きるあのであったとしてあ，長期の生 活の中で起きるものであるから, 実験によって取り出せるような あのではなく, したがって, 悠密な意味での検証・実証ができる あのではない。しかし, 本稿では, 以上述べてきたことから, 得 られた限りのデー夕に基づき原風景を風景生成現象としてとらま えるために必要な道具立て (用語抢よび考察枠組み) を整備し, 今後の議論に耐えうる形にして問題提起を試みてみたい。

\section{3. 先行研究の概観}

原風景に関する研究は, これまで幅広い研究領域においてなさ れてきており，全体としても質・量ともに既にかなり出揃ってき たと言える。それぞれの研究の性格に応じ, 「原風景」の用語定 義には幅があるものの, 原風景の持ついくつかの基本的性格が多 くの研究に共通するあのとして示されている。それらはすなわち,

(1) 原風景はほとんど全ての人にみられること

(2) 原風景に多くの人が肯定的・積極的意味を与えていること

(3) 原風景は対環境態度の基礎となること

(4) 原風景は幼少期（と青年期）に形成されること の諸点である。以下, これらを確認しつつ, 風景生成研究の観点 から検討を加える。

まず，(1)であるが，高橋らの研究で言及されていることを始め， 多くの研究者に共通する見解である ${ }^{10)}$ 。しかし，ここで，原風景 が「ほとんどの人にみられる」のは, 各被験者が既に原風景を生 成し意識しているからなのか，それとむ調査で回答を求められた ためにその趣旨に沿ってその場で過去の記憶を思い出して回答し たためなのかという疑問が生じる。実際, “はっきり”した原風 景（たとえば，イメージが明確である，想起頻度が高い，聞かれ てすぐ迷わず答える，等）と，そうでないあのの両者の存在は指 摘されて抢り, 関根は, 地方出身者の原風景がはっきりしている ことが彼の 1982 年の論文の新たな指摘であるとしている ${ }^{11)} 。 つ$ まり, 原風景に対する態度強度 ${ }^{12}$ の観点からの検討はそれまで無 かったということであり, また, 関根の研究を含めたそれ以後の 研究に打いても, このことを明確に指摘し検討を加えた研究はこ れまでにない(13)

次に(2)についてであるが, 多くの研究で, 原風景は単なる記憶 や思い出でなく, 「心のよすがを支え, 安定感・安息感の源」之 なるもの ${ }^{14)}$,「自分の現在を根底で支える大切なあのを発見する」 契機15)，また作家にとっては「造形力の源泉」目) となる，という ように原風景の機能が言及されている。このため, 原風景の想起 に伴う感情を調査項目に加える研究は多い。しかし, それらはあ くまでも「過去の記憶の想起に伴う感情」としてとらえられてお り, 多くの研究において原風景の持つ未来性の側面が指摘されて いるにも関わらず77)，原風景を，現在において新たに生成したも のとしてとらえそのメカニズムを探ろうとする研究はみあたらな い。

(3)屯, 多くの研究者の一致するところであり ${ }^{18)}$ ，また，これ之 (2)をあわせると, 計画・設計分野においても原風景を研究する意 義が認められることから，この分野に扔いても原風景あるいは 「心象風景」の研究がなされてきた。しかしそれらの研究では, 分野の性質上, 研究目的の設定に扔いて原風景等の内容の抽出あ るいはその現在の空間体験へ影響の検討に重きが置かれており, 原風景の生成メカニズムそのものを探った研究はみあたらない。
最後に，(4)についてであるが，これまでの原風景研究の被験者 の大多数が大学生であり，この結果が幅広い年齢層についても普 遍性を持つかどうかを裹付ける調查結果が報告されていないが ${ }^{19)}$, 今のところ，原風景の形成時期を幼少期，あるいは幼少期と青年 期 (思春期) とすることが一応の共通認識となっていること自体 は認めてよいであろう ${ }^{20)}$ 。ここで，風景生成研究の立場から言え ば，原風景の形成時期の厳密な特定よりむむしろ，ある場所での 体験が原風景として生成されるまでの経過, すなわち風景が対象 化されるために必要な時間経過や契機（体験枠組みの変化等）に ついての検討の方が，これらがこれまで十分に研究されてきてい ないことから屯注目される。つまり風景の成立のためには，上く 知られるところの「空間的な『引き』」ばかりでなく，時間的な 「引き」屯契機となり得るのではないかと予想されるが，しかし， このことについて触れているのは, 奥野が, 特に幼少期の原風景 は後年になるほど懐かしく思い出され, 若い頃にはわからなかっ た風景やイメージの意味がしだいにわかってくると述べている程 度であり, それ以上この点について取り組んだ研究はみあたらない。

\section{4. 残された論点の整理}

以上の先行研究の概観加, 次の 2 点を, 風景生成の観点加 みた原風景研究に残された論点としてまとめられよう。

\section{（1）原風景の「形成」と「生成」の区別}

まず，原風景の「生成」の現象がそもそ屯あるあのなのかどう かについてであるが，関根む指摘しているように，“はっきり” した原風景を持つ者が存在することから，故郷などの以前生活を していた場所の風景が後に明確に意識されるという現象があるこ と自体は, 認めてよいであろう。ここで，このような現象を，原 風景の「生成」ととらえ，一方，幼少期を中心とする時期に生活 していた場所の体験は, 原風景の「形成」の過程として区別する ことを提案したい。つまり，原風景の「形成」とは，後の風景生 成の素材となるような感覚や体験の断片が積み上げられる過程, これに対し, 原風景の「生成」とは, それが現在の価值観やかま えのあとに，以前とは違うあるひとつの全体像を持つあのとして 生成され直される過程として考えるということである。この区別 をした上で, これまで研究されてこなかった「原風景の生成」と はいかなる過程であるのかを，本稿では検討していく。そこにお いては，原風景の生成をうながすような，すなわち環境に対する かまえを变化させるような契機（時間的な「引き」や体験枠組み の变化等）のありように着目し考察を進める。また，「生成」々 は区別されるあのとして「形成」について考察することにより， これまで単に「幼少期」とされてきた原風景の「形成」には，他 の一般の風景之は区別される「原風景」の生成につながるための, いかなる意味之役割があるかについて検討できるあのと考える。

\section{(2) 態度強度の観点}

以上のように原風景の「生成」と「形成」を区別した場合，既 往研究が指摘するように「ほとんど全ての人」が，原風景を「形 成」してきているとは言えようが，しかし，必ずし屯原風景を 「生成」しているとは限らないと考えられ，件の“はっきり”し た原風景を持つ者などが，原風景を既に「生成」した者ととらえ ることができよう。既に原風景を生成したかしていないかは, 程 度の問題はあるにせよ, 態度強度に着目することによってとらえ ることができると考えられる。逆に言えば，原風景についての態 度強度に着目することは, 原風景の「生成」という現象を検出す るために有効であると考えられ，このような検討はこれまでにな いこと，また内容とともに強度を採取することが調查をより正確 なむのにすると考えられることからも，その意義を認められよう。

以上 (1)（2）上り, 被験者の居住歴や生活体験之その変化, 原風景の想起状況とその内容, および原風景に対する態度強度な 
どに着目した原風景の調查分析を行うという方針が得られた。

\section{5 . 原風景調査の概要}

前章で得られた方針に従い, 原風景調査を行った。ここで, 調 查目的が原風景の生成プロセスを詳細に検討することであるため, 統計的処理に耐えるほどのサンプル数を得るよりも, 数はある程 度少なくとも詳しい内容を得ることが重要であることから, 調査 方法は, インタビュー調査が主体となるが, 今回は, その上で調 查方法の効率化の工夫の試みとして，アンケートを併用できる部 分は適用を試みることとした。すなわち，まず以下の（1）のイ ンタビュー調查を予備調査的に行い, その結果を検討して（2） のアンケート調査の用紙を注意深く設計し, 調查を行った。

（1）原風景をスケッチし, その内容と想起状況, 生活体験等に ついて説明してもらうインタビュ一調査 (対象 : 東京在住の学 生 19 人, うち男性 12 人, 女性 7 人, 年齢 20- 25 歳)。

（2）現在までの居住歴, 風景体験, 原風景スケッチ及びその内 容々想起状況などを調査項目とする自由筆記回答形式のアンケー 卜調査。この調查では, 写真撮影 (帰省の際に原風景の場所を 撮影, また現在の住居周辺屯撮影）屯被験者自身に依頼（対象： 東京在住の学生 22 人, うち男性 17 人, 女性 5 人, 年齢 $20-$ 27 歳。また, このうち調査（1）との重複回答者は 4 人)。 次に, この時点で (1) (2) の調査結果を検討したところ, 転居経験のある場合にはその前後の心境変化等についてさらに詳 しく調べることが原風景現象に関する考察を深める上で重要であ ると判断し, 以下の（3）の追加調査も行った。

（３）まず簡便な予備アンケートにより, 原風景に対する態度強 度がある程度強いと考えられる回答者を選定。次に選定された 回答者に対し, とくに上記心境变化や想起状況之頻度について 詳しく聴取するインタビュー調査を行った（インタビューまで 進んだのは 6 名, うち男性 3 人, 女性 3 人, 年齢 $22-36$ 歳)。 以上の如く調査方法の改良工夫を試みてきたが, 最後に, アン ケートでは十分な筆記回答が得られなかった項目・被験者のデー 夕などの補強を図ると同時に，3つの調査いずれのデー夕も有効 活用できるよう, 必要に応じ適宜各調査の回答者に対し追加の再 インタビューを実施し, 相互の調査で項目の抜落や精度の顕著な 違いがないよう不足デー夕を補い，いずれのデー夕も同等に扱え るようにデー夕を整えた。この結果, 居住歴, 生活体験, 原風景 スケッチ, その内容と想起状況及び頻度, 転居前後の心境变化等 について回答が得られた合計 43 サンプルが，本報告での考察対 象の有効サンプルとなった。次章にその内容をまとめて示す。

\section{6. 調査結果}

調査の結果得られたデー夕にみられる傾向を, 以下, 本研究の 枠組みに沿い, 原風景の「形成」の時期にあたると思われる体験 のありよう, 態度強度の強弱とそれに影響を与える要因, 体験枠 組みの変容の観点から整理し, 先行研究の結果と比較しつつ示す。

\section{（1）原風景の「形成」の時期の体験のありょう}

「幼少期に心に刻まれた風景が中核をなす」21) との先行研究結 果之同様の傾向が, 本調査に掞いても大多数の回答者を通じみら れた。その典型例としては, 通学路や子どあの頃の遊び場を原風 景として挙げた回答等を挙げることができる（図一1に例)。

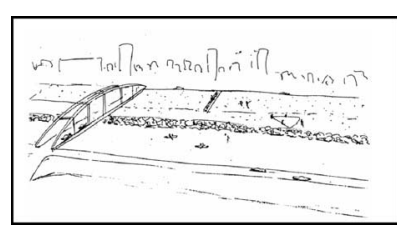

図-1 小学校への通学路

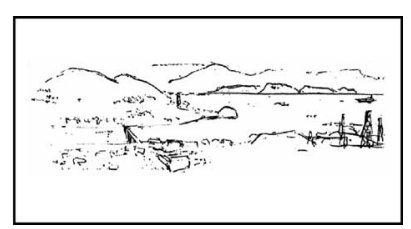

図一２遠足でみた眺め
また，遠足や小旅行など，一応当時の生活圏内ではあるが，毎 日の生活の中ではみられないという意味で非日常的な体験がもと となった原風景屯多くみられた22) (図一2に例)。

また，「原風景の中核に「家」が存在している」との既往研究 の結果 ${ }^{23)}$ 之同様の結果が本調査に扔いてもみられた。とくに, 帰 宅途中の道で, 家や家の近くのものがみえてきたときに感じる 「ああ家に䚻ってきた」という実感・安心感など，なんらかのス トレスからの解放によって生成されていると考えられる風景を挙 げた者が多かった。そして, これらの例では, 毎日の生活の繰り 返しの中で, 帰宅時等にこのような風景生成がなされては自動化 されていくことがみてとれた（後出の回答 $\mathrm{A}$ 参照)。

\section{（2）原風景に対する態度強度の強弱とその要因に関するデータ}

地方出身者の場合, 態度強度の強い明確な原風景がみられるこ とについては, 既往研究の結果と同様の結果が概礼得られ, とく に, 一枚の絵として明確なまと まりを持つ実景が存在するよう な地形的条件の場所に育った者 は原風景を生成しやすいと考え られる等の傾向が本調査によっ ても裏付けられた ${ }^{24}$ (図一 3 に 例)。

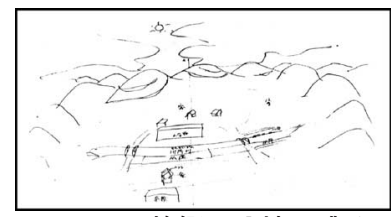

図 -3 故郷の盆地の眺め

またこれに加え, 実景としては地域の全体像が見渡せないよう な地形的条件の場所であっても，見えている断片の景観要素が地 域を象徵する歴史的意味を持つなど地域の意味的まとまりがとら えられる場合には回答者が強い態度強度を示す傾向があり原風景 の生成が認められることを示すデー夕が得られた（図－4に例）。

また, 帰省の際に到着する新幹線の駅などからの眺めを原風景 として挙げる者が複数あった（図一 5 に例）。これらは，形成当 時にはそれとして体験・生成したことのない風景であるが，「やっ と故郷に帰った」などの強い安堵感を伴って体験・生成されるこ とから原風景として意識され, 故郷での様々な体験のインデック スとして働くという意味で故郷の地域を代表する眺めとしての機 能を持つようになることがみてとれた。

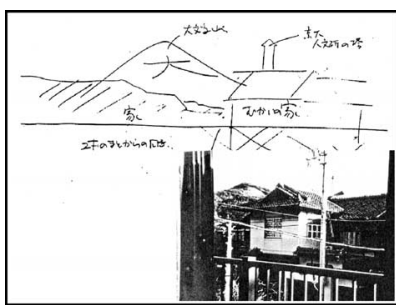

図-4 家の空からの眺め

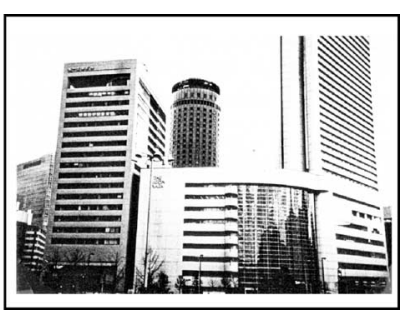

図一５帰省時に着く駅からの眺め
また, 必ずしも, 既往研究の言うように自然豊かな地方でなく, 都市部の出身者であっても, 遠方への転居の経験がある場合は明 確な原風景の生成がみられ，逆に，以下の例にみられるように， 遠方への転居経験のない回答者（例：回答 A,B）は原風景につ いての態度強度が弱く, 従って原風景が未だ生成されるに至って いないと考えられるという傾向が得られた。

回答 $\mathrm{A}$ ：私に故郷というものはないかもしれない。それは頻ぱ んに帰るので，別になんの感慨も感じないから。あえていうな ら, 駅から帰る道を歩く之き, 田の中の一本道が通っているの だが, その風景は気に入っている。

回答 B (生まれた時から 24 歳の現在まで転居の経験が無い者)： 原風景はよくわからない。難しい。比べる風景がない.・という か, 今住んでいる場所以外に慣れ親しんだ場所がないから。

\section{(3) 生活の体験枠組みの変容の観点から}

今回調查で得られた 43 サンプルは，(1)転居経験がほとんどな い被験者（転居が全く無いか，あったとしても，同一地区内での 
転居か，1年程度の仮住まいなど） 6 名，(2)転居回数が 1 回程度 の者 (典型的には大学入学時まで同一住所に住み, 入学々同時に 上京した地方出身者）18 名, 拉よびその他 19 名（様々なパ夕ー ンで複数回の転居経験がある者）に分類でき, また最後の 19 名 はさらに(3)転居先に外国も含まれる者 6 名之(4)それ以外 13 名に 分類できた。以下，これを分類(1)～(4)と示すこととすると，上記 (2) の結果に扔いてもみられたように, 地域の地形的特徵自体 よりむむしろ, 転居経験などの生活における体験枠組みの变化が 原風景に対する態度強度に影響すると考えられることは, 分類(2) の 18 名全員が明確な原風景を回答していたこと（うち，“一枚の 絵”夕イプの原風景 11 例, 実景では一枚の絵でなくとも地域を 象徵する景観要素が含まれるもの 3 例, 遊び場など自宅周辺の近 景 4 例。なお以上と重複し, 帰宅あるいは帰省時の安堵感之顕著 に結びついているあの 4 例あり), また, 分類(1)の 6 名中 5 名が 明確な原風景を回答しなかったこと（3 名は上記回答 B の上う に原風景が不明あるいは無しと回答, 2 名は小旅行や遠出をした 時の風景を回答するむ, 原風景としてというょりもむしろ最近の 抢気に入りの場所としてとらえていると回答。な打残り 1 名は子 供の頃上く歩いた近所の川の土手からの眺めを原風景として挙げ

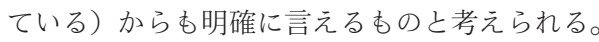

また，原風景について回答しづらいと言うなど態度強度が弱く， 原風景を未だ「生成」するに至っていないと考えられる者は, 先 の回答 B の例にもみられるように, 回答しづらさの原因として 比較対象が想定しにくいことを挙げる傾向があり, 一方, 原風景 を既に生成していると考えられる者は, 以下の回答 C の例にみ られるように, 原風景が, 他の場所での風景体験における比較基 準となっていると自覚的に答える傾向があった。これらは, 風景 とは一般に以前の風景との対比により生成されるとする, 風景生 成研究の既往知見 ${ }^{25)}$ と合致する結果であると言える。

回答 $\mathrm{C}$ ：育った場所，ということで，何も考える基準を持たずに 成長した時期が広島であり, そこで考える基準が作られている と思う。確かに埼玉も東京も“育った”之いう意味ではその時 の環境には違いないが，そこで環境や新しい感覚を身につける 上きには広島におけるあの之の比較がなされているので, その 点で常に首都圏で暮らしていた人とは決定的に異なっている・。 また, 原風景が明確であるという意味で態度強度の強い者の中 にも, 原風景を強い感情を伴い想起する者とそれほどでない者が みられた。このうち, 例えば「(故郷を離れた現在の環境が) 嫌 だ，ストレスを感じる」「(故郷に）帰りたくて仕方ない」等，感 情的内容を含む回答をする者は, 原風景の地で過ごした期間が長 く転居回数が少ない者 (分類(2)，それもとくに転居から間もな い者に多く, 一方, 転居回数の多い者 (分類(4)) は感情的な回答 をする者は少なく, 原風景について淡々と答える者がほとんどで あった。

またこの他, 外国居住経験者（分類(3)）が, 母国と外国の両方 にそれぞれ原風景があると答えている回答例が複数得られた（6 名中 3 名)。これらは, それぞれ態度強度の強い, 明確な原風景で あったことから，複数の原風景が生成された例であると考えられる。

\section{7. 原風景の「形成」プロセスに関する考察}

調査結果の（1）でみてきた傾向から, 原風景の場所は, 一種 の非日常的体験あるいはストレスからの解放などを契機に, 当時 は当時なりの（この時点では, 原風景としての風景生成ではない にしろ）なんらかの風景生成がなされた場所であると考えられる。 また, 州宅時の風景の場合に顕著なように, いったん生成された 風景む, 日常生活の中で自動化されていき, その結果, 生成之自 動化を何度む繰り返すむのと考えられる。

以上よりまず，原風景の「形成」の過程とは，風景の生成と自
動化を繰り返す過程であると考えられるが，ここで，先に2.で 確認したように「自動化」の現象は，「身体化」でああるという 側面を持つことから, さらに考察すると, 次のようにとらえられ よう。すなわち, 生成された風景が繰り返し「自動化」される之 いうことは, 風景として意識されなくなっていくということであ る。しかし一方, 「身体化」という機能に着目して考えると，そ れは，その場所の環境になじんだ身体を獲得していくことである と考えられ，よって，繰り返し「身体化」が起こることにより， 体験者はその場所といわば一体化していくあのと考えられる。す なわち, 生成された風景が繰り返し「自動化」していくことは, 体験者がその風景を喪失してしまうことではなく, むしろ, 繰り 返される「身体化」によって，心身ともにその風景となじみ，自 己がその場所と一体化していく過程であると考えられる。

以上の考察を, 調査結果にみられた, 原風景を未だ生成してい ない回答者の例之照らし合わせて考えると，この時点で原風景が それとして生成されにくいのは, 体験者がまだ原風景の「形成」 時期の中にいる間は，以上述べてきたようにその場所が自己と一 体化していて切り離し難く, そのために, この時点では原風景之 して対象化されにくいからであると解釈できる。

また一方, これに加え, この時点で原風景が対象化されにくい 原因の他の一因として, 調查結果の（3）でもみてきたように, 形成期の体験が, 対比の対象となるような風景が他にない状態で の体験であることが挙げられよう。このことと, 風景が一般に以 前の風景との対比により生成されると考えられることとをあわせ て考えると, 原風景が他の風景と区別されるのは, 対比の対象之 なるような風景がほとんどない状態で，いわば純粋に体験した場 所での体験を素材に生成された風景であるという点にあると考え られる。つまり, 原風景の「形成」期の体験之は, 単に幼少期の 体験であるというよりも，比較基準がほとんどない状態での体験 であることが特徴的であるととらえることができよう。

このようにとらえると, 外国居住経験者が複数の原風景を生成 したと考えられるという結果は, 生活における基準や体駼枠組み が極端に異なる地においてはそれぞれに原風景が生成されること があることを示す例であると考えられる。

\section{8. 原風景の「生成」プロセスに関する考察}

調査結果から，転居等により異なる環境に身を置くようになる ことが，原風景の生成の大きなきっかけとなることがわかったが， ここでは, それがごのようなメカニズムによるのかについて考察 するため, 再度, より詳細に結果をみていく。

まず以下にみる例は，大学入学と同時に上京するまで沖縄で育っ た回答者であり，地方出身者が明確な原風景を持つというケース の典型例とも言えるようなケースである。

回答 D：東京に来た当初は，見晴らしがなくて非常にストレス を感じた。(中略)両親の実家のある場所は, 畑が広がって手っ かずの海があった。(中略) そこでは高台から見下ろした時の 景色が好きだった。マッチ箱のような家々と広がる海。夜にな ると遠くの灯台の光が見えた。

上記を始めとするこの人の回答内容を総合すると, この人にとっ ては, 広い見晴らしとは, わざわざ旅に出て見に行くようなもの ではなく, 生活の中にあってあたりまえのむのであったという。 そのため, 上京と同時に突然, 日常的には広い見晴らしが得られ ないような環境に身を置くことになったことは, この人にとって 大きな環境の変化であると言え，そして，この「見晴らしがない」 というストレスが，この回答者にとって原風景を生成するための きっかけになったと考えられる。このように, 街のなかの見通し・ 見晴らしの視距離の違いなどが原因と考えられるストレスを, 転 居直後に強く感じたという回答者は, 原風景に対する態度強度の 
強い回答者に複数みられ, このことから, 原風景の場所の地形的 特徵自体というよりむむしろ, 原風景の場所と転居先の場所との 空間構造の差異があたらすストレスが，原風景の生成の契機とし て働くものと考えられる。

また, 以上より, 原風景の生成につながるための形成過程の役 割について考察すると, それは, 長期間をその地で過ごすことに より, その地の空間特性が身体化し, 知覚に慣れが生じたり, 居 心地よく感じるようになることにあると考えられる。つまり, 原 風景の形成過程は, 環境に対する「かまえ」が固定されていく過 程としてとらえられ，そして，一旦かまえが固定されてしまうと， そのかまえでは快適に生活体験ができない場所では, そのストレ スにより原風景の生成が起こりやすい，と考えることができよう。

以上の考察を，再び調査結果と照合してみると，転居のない場 合は原風景の生成がみられない場合が多いという結果が，かまえ を大幅に修正する必要がなかったためと解釈できること，また， 原風景について感情的に答える者が, 転居回数の多い者に対し少 ない者, また転居から間もない者の方が多かったという結果が, かまえの固定しやすさとその保持状況の点から説明できることか ら, この, かまえと環境のずれによるストレスは, 原風景が生成 される契機の一つとなるととらえてよいであろう。

さて一方, 以上の説明のほかに, 転居が原風景生成の契機とな りやすい原因は，転居ということが，原風景の場所と物理的空間 的に離れ，時間的にあ「引き」をとることになるため，それまで 一体化してきた場所が「対象化」しやすくなるからではないかと 考えることもできる。以下では，このことについて検討してみる。

まず, 先ほどの回答 D の例では, 回答者は原風景として両親 の実家のある場所を挙げている。つまり, 日常生活の中ですっか り自動化してしまっている環境でなく, 当時においても, そこを 訪れることが遠足や小旅行程度の非日常性はあるという場所が原 風景の場所となっており, 当時は当時なりの風景生成がなされた 場所であると考えられる。そして, その場所において何度か生成 されたであろう風景群（場所としては同一であって屯生成の度に 少しずつ違う様相であっただろう風景群, あるいは少しずつ違う 場所で生成された風景群) が, 原風景として生成される際にはひ とつに束称られ, 先の回答のような形で, 故郷の様子を最も代表 する眺めとしての「原風景」となって生成されたものと考えられ る。またこの他, 調查結果の（2）でみてきた, 帰省の際に到着 する駅からの眺めなどが故郷の場所全体を代表する眺めとして働 き，原風景として挙げられる例に扔いても，それが故郷のインデッ クスとして働いていることから，これらの例においても，それま でその内部に居たがために特にまとまりをむって意識されること がなかった個々の場所が，故郷というひとつの場所として束ねら れることにより原風景が対象化されることがみてとれると言える。 また, より顕著に以上のことを自覚的に答えた回答例もみられた。 回答 $\mathrm{E}$ ：広島にいる之きは別に故郷なんて感じたことはなかった。

すっげー街中に住んでいたもんで(中略)。だけよ゙東京に住み始 めてから感じるのは故郷は広島って街全体なんだなっていうこ と。新幹線で帰省するとき広島駅に近づくにつれて, いろんな 思い出のあるものが見えてきて, “あ一, 帰ってきたんだな” そんな感じになる(中略)。街中でも, 友達の家, 小学校, 幼稚 園, 公園, 電話ボックスや自販ひとつでも, 心の底に残ってい るものはすべてひっくるめて故郷の要素群なんだろう。

この回答者は, それぞれの「思い出」が作られた時のそれぞれの 体験において，それぞれの風景を生成してきたのであろうが，そ れらが「全てひっくるめて」束ねられ，原風景となっていると言っ ている。この例加ら, 原風景の生成において対象化されている のは，個々の対象物や記憶の中の風景そのものであると言うより む, むしろ自分が以前一体化していた場所全体であり, 場所が核
となることによって，原風景はあるひとつのまとまりとなり，ひ とつの風景に束㸚られると考えられよう。

この他にも, 調查結果の（2）に扔いても報告した通り, 原風 景の場所が全体像を見渡せる地形的条件を有さなくても，意味的 に地域のまとまりをとらえられる場合には後に原風景の生成がみ られる傾向があることから，原風景は，必ずしも実景や体験当時 に生成された風景と合致しなくとも，場所が核となり，ひとつの 風景として束ねられ生成されるむのと考えることができよう。

以上のように, 場所が核となって原風景がひとつの風景と束秝 られるという原風景の生成メカニズムを「場の束称」と呼ぶこと にすると，その機構は図－６のような模式図で示すことができる。 また，時間軸上では，当時の体験においては，風景の生成と自動 化はそれぞれある時間間隔でなされたであろうが，原風景の生成 は, そのように生成された風景群を, 稠密化して束ねあげるよう な生成であると考えられる。

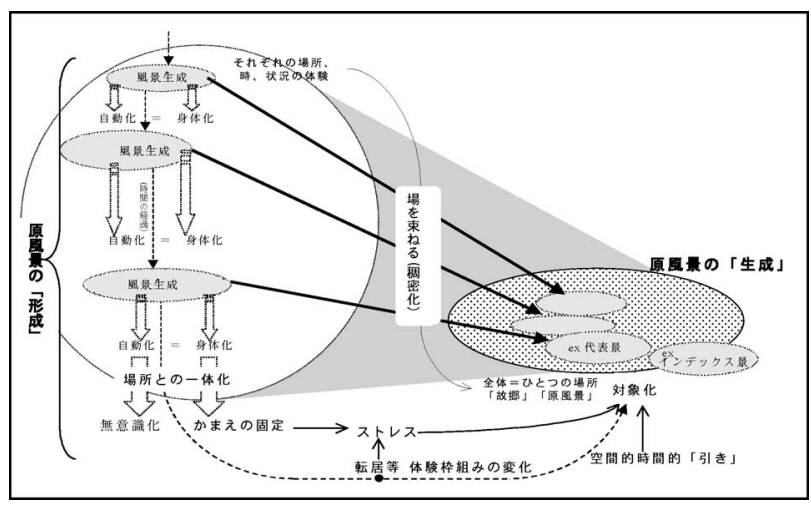

図－6 「場の束ね」による原風景生成メカニズム

\section{9. 原風景の形成・生成および自己アイデンティティ保全の機構}

ここまでの考察で, 長期間を過ごした場所から転居した場合, それまでの固定したかまえでは新たな環境に対処できないという ストレスが生じるが，その時，最む居心地よく過ごすことのでき た場所が核となって原風景が生成されるというメカニズムが確認 された。このことから, 原風景の成立のためには, その形成過程 および生成過程の両方が必要であり,「形成」の過程を経たもの であるからこそ「生成」の契機が与えられるあのであると言えよ う。ここでさらに，その場所に対する居心地や感覚を手がかり之 して場が束称られることに着目し，これを「感覚の束权」と呼ぶ ことにすると，原風景の形成から生成へのメカニズムは，次のよ うに説明することができる。すなわち, かまえが固定し，身体の 感じ方が惰性化している体験者が，新たな環境で感じる感覚の違 和感により, 最も居心地のよかった場所での感覚を比較基準とし て自覚し, それにより, 当初はまとまりがなかった故郷の地が経 験のまとまりとして束㸚られるという，「感覚の束权」を通じた 「場の束対」の機構である（次ページ図 -7 の模式図の左下部分 参照)。

また，原風景は，これまでにも自己アイデンティティとの関わ りのあとに語られることが多かったが, 本調査結果から言えるの は, 原風景の生成をきっかけに, 自己アイデンティティがむしろ 後から確認されるという機構である。すなわち, 上であ述べたよ うに, 原風景の場所は, 風景の生成と自動化を繰り返すことによっ て身体化し，自己と一体化した場所であると考えられ，よって， 原風景の場所の環境から受ける刺激によって空間の特性に従った 身体の感じ方が培われることが, 原風景現象の生じるための条件 であると考えられる。また, 原風景は, 比較基準がない状態で体 験されたという意味で純粋に体験されたと考えられること屯先に 確認したが，他に比較基準がないからこそ，その場所で培われた 
身体性が自らの身体の感じ方の基本となると考えられよう。そし て, 故郷での生活の様々な場面で味わった感覚が故郷という場所 を核に束ねあわされる際に, その場所での感じ方になじんだ特性 を持つ自らの身体のあり方が自覚され，それが，本来の自分の姿， すなわち自己アイデンティティの核として自覚されるむのと考え られる。このことを「身の束対」と呼ぶことにすると，原風景の 成立メカニズムは，「感覚の束対」を通じ「場の束利」が起こる ことによって説明され，そこにおいて場が束㸚られると同時に身 が束㸚られるという自己アイデンティティ保全の機構もみられる と言えよう(図一 7 )。

以上より，原風景とは，単なるノスタルジーではなく，あのを 見る枠組みの転換がそこにみられることを，デー夕に基づき確認 できた。

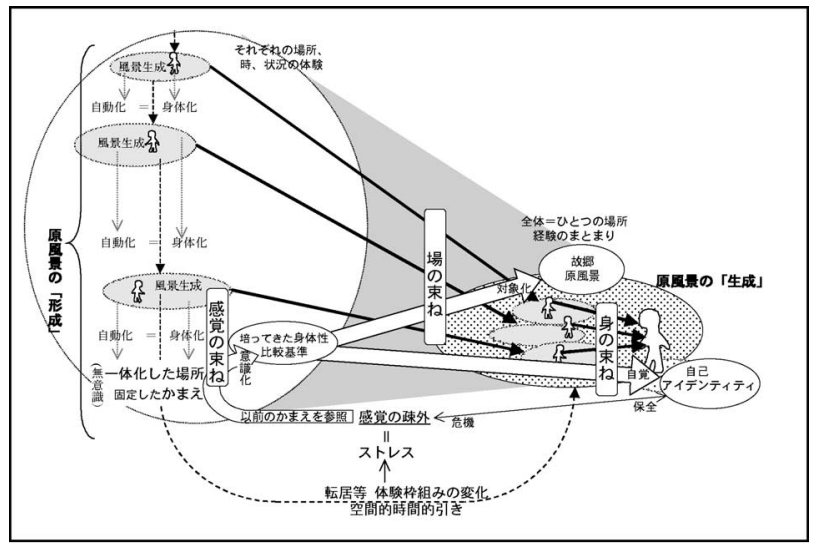

図ー7 原風景の成立メカニズム

\section{0. まとめ}

（1）転居等を契機に新たな環境に置かれた体験者が故郷の風景 を「原風景」として生成する現象について, 態度強度に着目した 調査抢よび分析を行い, 原風景の成立プロセスとそのメカニズム について, 説明に必要な「原風景の形成」「原風景の生成」等の 用語を提案して補いつつ考察・説明した。

（2）原風景の形成之は，生成された風景が繰り返し身体化され ることにより, 自己とその場所が一体化する過程であり, かまえ が固定していく過程として考察された。また，比較基準がない状 態で体験されることが特徵的であることを指摘した。

（3）原風景の生成は，典型的には転居を契機に，それまで住ん できた場所全体が対象化される過程であり，その際，転居が契機 となりやすいのは，空間的時間的な引きが与えられることによる 「対象化のしやすさ」とともに，それが生活におけるかまえを大 幅に修正する必要を生じさせるという「ストレス」が原因である と考えられることが考察された。

(4) 原風景の形成から生成に至るプロセスを考察し, 原風景の 成立メカニズムは, 「感覚の束利」を通じ「場の束対」が起こる ことによって説明され，さらに，そこにおいて場が束ねられると 同時に身が束㸚られるという自己アイデンティティ保全の機構も みられることを確認した。

\section{補注及び弓用文献}

1 ）意味はテクストとテクストの関係性において産出されるという意味生 成の記号論（クリステヴァが提示した間テクスト性の理論）から「生 成」の用語を採った。風景生成研究の既往研究としては, 吉村晶子 (1998)：『東関紀行』の分析を通じた動態的風景記述モデルの構築： ランドスケープ研究 61(5)，675-680などがある。

2)「自動的処理」とも呼ばれる。箱田裕司編（1993）：認知科学のフロン ティアIII：サイエンス社などを参照。
3 ) 村田純一 (1995) : 知覚と生活世界 : 知の現象学的理論 : 東京大学出 版会参照。

4 ）芸術作品を対象とする場合は「鑑賞」であるが，ここでは対象を広く 自然等も含めているため「観照」とした。この用字は谷田部康幸（19 92）: 美術の鑑賞とその望ましいありかた：国士舘大学文学部人文学 会紀要 25 を参照した。

5 ）異化 estrangement，前面化 foregrounding とも呼ばれる。Winfried Nöth (1990) : Handbook of Semiotics: Indiana University Press 等を参照。

6 ）アラン・ロジェ (1995)：風景と環境—その「言分け理論」をめぐっ て：SD1995 年 4 月号参照。

7 ） カントの言う無関心性。佐々木健一（1995）：美学辞典：東京大学出 版会の「美的態度」の項などを参照。

8 ）一般に「態度」の概念は, 長期わたって持続される反応傾向を指し, 一時的な構えとは区別される。一方，「構え」の用語は，「個体が，あ る特定の状況に対して予期をしたり行動の準備状態をとることや，認 知や反応の仕方にあらかじめ一定の方向性をもつこと」(外林大作ほ か編 (1981)：誠信心理学辞典：誠信書房）を指し，「一時的なもの屯 あれば長期にわたって個体の情報処理に影響するものもある」（中島 義明ほか編（1999）：心理学辞典：有斐閣）とされていることから, 風景現象を動態的によらえるにあたって有効であると判断し，用いる こととした。ひらがな表記するのは，「構え心理学」の分野における 狭義の定義と区別するための用心である。

9 ) 勝原文夫（(1979）：農の美学：論創社）は，純粋個人の原風景の他に 国民的原風景が存在するとし, また, 進士五十八（東京農大造園学科 庭園学・造園学原論研究会編（1996）：原風景の研究：東京農業大学 出版会）はさらにこれに加え人類レベルの原風景を想定するが，本稿 で扱うのは個人の原風景に限る。

10）高橋義孝（1978.11）：原光景之原風景：思想 653，27-35 参昭。また, (1)扝よび(2)は，茂原朋子（(1991）：青年の "原風景" の特性と構造に 関する研究 : 日本都市計画学会学術研究論文集 26) が先行研究の成 果として認めている。

11）関根康正 (1982)：原風景試論：季刊人類学 13(1), 164-193

12）原風景のようなものを対象とし「態度強度」を適用することに疑義が あるかもしれないが，少なくとも，「対象への評価がすでにはっきり しており，質問されれば瞬時に答えることができる」者と，「対象へ の評価がまだ定まっておらず，答えるのに時間がかかる」者が存在す ることは関根屯指摘している通りであり，以上は態度強度の指標であ る「態度のアクセスビリティ」としてとらえられる（以上引用部分は 今城周造編著（1993）：社会心理学：北大路書房より）。また, 態度の 内容とともに強度を分析することは，調查に伴うバイアスを修正する のに有効であるとされているが，実際，今回の調査で屯原風景が不明 確な回答者に複数回面接するとその度に違う風景を答えたケースがあ り, 原風景を対象とする場合にもこのような強度に着目することが調 查結果をより評価できるむのにすると考えられ，以上より「態度強度」 の用語においてとらえることとした。

13）星野命・長谷川浩一（1985）：青年の「心の風土」としての原風景： 学会連合日本の風土調查委員会編「日本の風土」所収：弘文堂が， 「幼少期の体験に…明快な記憶と積極的な意味づけをしてくれる」こ とを期待して保育科等の学生を調查対象に選んでいることにみられる ように, 多くの研究者たちが態度強度の強弱の問題があることを認識 していることは認められる。しかし，この強弱の問題こそが現象の様 相を示す一要素であるととらえ扱うものはない。

14）星野命ら前掲論文参照

15）井上佳明（1995）：原風景の心理学的研究：鹿児島大学法文学部紀要

16）奥野健男（1972）：文学に打ける原風景：集英社

17）たとえば関根は前掲論文で原風景を「未来に向かって保持し，追い求 めようとする今の心に生きている風景である」として抢り，その未来 性を積極的に取り上げて論を展開している。

18）井上佳明前掲論文における原風景の定義に含まれる。井上は先行研究 の検討を行いそれに基づき原風景の定義を行っている。

19）このことは井上佳明（前掲論文）が指摘している。

20）「造園用語辞典」(東京農大造園学科編（1985）：彰国社）の「原風景」 の項（p.173，進士五十八による）では，「幼少年期（7-8 歳ごろま で）ならびに思春期 (20 歳前後)」とされている。

21）関根康正の前掲論文参照。関根は，彼の調査で得られた原風景のデー 夕を 7 つの要点によりよく分類整理しているが，これはそのうち「要 点 2 」に該当する。

22）関根康正の前掲論文では，要点 3 として「自然のうちに思いがけず見 た不思議, 恐怖の風景が強く心をとらえる」が挙げられているが，本 稿の調査結果では不思議や恐怖というほどの感情や強い非日常性のみ られる結果はなかった。

23）関根康正の前掲論文の要点 4 である。

24）関根康正の前掲論文の要点 1 である。

25）前掲吉村晶子（1998）参照 